\title{
Witness Protection in Kosovo: Progress and Challenges
}

\author{
Kadri ARIFI \\ AAB University, Kosovo \\ kadri.arifi@gmail.com
}

\begin{abstract}
The role and importance of the witnesses in criminal procedure in fighting serious and organized crime, corruption, terrorism and preserving the public security have continuously increased. Law enforcement institutions increasingly face with difficulties in the process of proving criminal acts in the judicial processes because of their complexity in providing sufficient evidence during the criminal investigation procedure. Therefore, besides the reactive investigation methods and application of special crime investigation measures, establishing a legal infrastructure and capacities for the implementation of witness protection concept is necessary as well. Kosovo government and institutions declared fight and prevention of all forms of organized crime, corruption and terrorism as a priority and up to now, it was evaluated that a great job was done in drafting legislation and strategic documents in the law enforcement field as well as increasing the operational capacities of law enforcement institutions. Regarding the witness protection in Kosovo, progress is achieved in improving legislation and establishing special structures for implementation of witness protection programs, but still remain some challenges that Kosovo law enforcement institutions face such as international cooperation and geographic, cultural and social specifics.
\end{abstract}

Keywords; witness protection, legislation, Kosovo, criminal procedure

\section{Introduction}

Organized crime, corruption and terrorism are serious concerns for national governments and international organizations as well. Financial power and use of modern technology by criminal and terrorist groups made that forms of organized crime and terrorism be more sophisticated and represent serious challenges for law enforcement institutions in combating and prosecution of these acts. In fact, competent institutions, through operational techniques and different sources can provide trusted information regarding criminal activities of individuals or criminal groups, but, providing evidences for judicial processes remains a challenge especially when these groups act in complete secrecy and pose threat for the life and safety of witnesses and members of their families. "At the national level, organized crime (and corruption cases) can be some of the most difficult and complex to investigate and prosecute. Disrupting or dismantling criminal groups requires getting information about actors, activities and financial dealings that can be difficult to obtain because of the secrecy of their operations and because corrupted officials are often paid to alert and protect them from such investigations."1 Providing evidence in judicial processes through witnesses is an issue that in its administration requires will, professionalism and investment in managing protection programs. "The ability of a witness to give testimony in a judicial setting or to cooperate with law enforcement investigations without fear of intimidation or reprisal is essential to maintaining the rule of law. Increasingly, countries are enacting legislation or adopting policies to protect witnesses whose cooperation with law enforcement authorities or testimony in a court of law would endanger their lives or those of their families. ${ }^{2}$ According to the Kosovo Law on witness protection the protected person means the person to whom the protection measures are applied and who in the position of witness or damaged party, shall notify or witness on the facts and circumstances, that comprise an object of relevant proof in a criminal procedure, for criminal offences foreseen in paragraph 1 of Article 4 of this Law and due to these notifications or proofs, is in a serious risk situation, and the person, who expiates the criminal sentence or is accused in criminal procedure, towards whom the special protection measures shall be applied, because of cooperation,

\footnotetext{
1 http://www.unafei.or.jp/english/pdf/PDF_GG4_Seminar/Fourth_GGSeminar_P3-19.pdf

2 UNODC, Good Practices for the Protection of Witnesses in Criminal Proceedings Involving Organized Crime, United Nations Office on Drugs and Crime, UNITED NATIONS Wiena, 2008, pg.1 
notification and declarations made in criminal procedure, for criminal offences foreseen in paragraph 1 of Article 4 of this Law and that for these reasons, is in a serious threat situation. ${ }^{1}$

\section{Kosovo stand point}

In the security and crime combating field, Kosovo institutions with the international assistance, mainly by the experts from European Union (EU), Organization of Security and Cooperation in Europe (OSCE), United Nation Development Program (UNDP), United States Agency for International Development (USAID) and many other organizations present in Kosovo, have adopted legislation in line with European Standards, which require stability of institutions, guaranteeing democracy, the rule of law, human rights and respect and protection for minorities. The Kosovo Constitution defines the priorities in the field of security and the role of state security and law enforcement institutions. Kosovo now has a legal infrastructure of witness protection in Kosovo. Firstly Criminal No. 04/L-123 Procedure Code of Kosovo, Chapter XIII Protection Of Injured Parties And Witnesses, stipulates Petition for Protective Measure or Anonymity Article 221, Order for Protective Measures Article 222, Order for Anonymity from the Public Article 223, Order for Anonymity from the Defendant Article 224, Form of Order for Anonymity Article 225, Prohibition of Questions that may Reveal Identity Article 226 and Special and Extraordinary measures, ways and procedures for witness protection and cooperative witnesses are governed by the Law on Witness Protection, Law No. 04/L-015, Witness Protection Article 227. "A major step in the investigation under the previous Criminal Procedure Code or under the new Criminal Procedure Code is the taking of pre-indictment statements from witnesses. This can be taken in three ways: pretrial interviews, pretrial testimony and special investigative opportunities. The State Prosecutor is not required to use all the methods, but having three options creates flexibility." ${ }^{2} \quad$ Law no. 04/I-015 on Witness Protection Law regulate special and extraordinary measures, ways and procedures for witness protection and cooperators of justice. Considering the entirety of laws regulating the field of investigations and criminal procedure, we may say that in the aspect of establishment of legal bases, great progress has been achieved in creation of legal conditions for witness protection programs implementation. Although, as European Commission states in the Kosovo Progress Report, the government needs to approve the rules of procedure of the inter-ministerial working group on dealing with the past and reconciliation and it needs to adopt a transitional justice strategy. In general, there continues to be insufficient political support and a lack of proper mechanisms to gather information relevant for investigations regarding war crimes and missing persons. Witness intimidation continues to be a concern, although the police have made good progress establishing a witness protection directorate. ${ }^{3}$ Establishing and strengthening the law enforcement and security institutions was supported by international missions and organizations in Kosovo and this helped implementing best practices and standards internationally accepted. Therefore, in the attempts of establishing functional and effective mechanisms in combating crime, the Directorate of Witness Protection was established, as a specialized and competent unit for implementing protective measures. Of course, it requires time for total functionalization and creation of the conditions for implementing witness protection programs. "A witness protection directorate has been set up within Kosovo Police and continues to be supported by EU and EULEX experts. In accordance with the law on witness protection, the witness protection committee, consisting of the chief state prosecutor, the head of the KP investigation unit and the director of the witness protection directorate were established in September 2013. Kosovo needs to sign agreements for witness relocation"4

\section{Witness Protection Program}

"The experience of many countries demonstrates that effective measures to defeat organized criminal groups require the cooperation of criminals who are willing to cooperate with the law enforcement officials and testify against conspirators. Such cooperation is impossible without the ability of the prosecutors and law enforcement officials to provide sufficient protection for individuals." ${ }^{5}$ For many reasons, in complex cases of criminal prosecution of individuals or criminal groups, witnesses can be protected only through special programs, by special laws and managed by legally foreseen organizational

\footnotetext{
1 Law no. 04/I-015 on Witness Protection, pg.1

${ }^{2}$ Smibert, Jon. Guide to the Criminal Procedure Code of Kosovo, Office of Overseas Prosecutorial Development and Training, US

Embassy, Prishtina 2013, Pg.48-49

${ }^{3}$ European Commission, Kosovo Progress Report 2014, pg. 22

${ }^{4}$ Ibid, pg 51

5 OSCE, Witness Security and Protection in Kosovo; Assessment and Recommendations, OSCE Mission in Kosovo, 2007. Pg.19 
structures. "The primary objective of any witness protection program is to safeguard witnesses in cases of serious threat which cannot be addressed by other protection measures in cases of special importance where the evidence to be provided by the witnesses (including victims) cannot be obtained by other means." The issue of witness protection is an important one not only within national framework but international one in crime combating as well. Witness protection programs are applied in the judicial processes for war crime investigations in various international tribunals. Also, determining internationally accepted standards for whiteness protection is very important in the international aspect. According to the United Nations Office on Drugs and Crime (UNODC) some of the most important elements for the establishment and operation of witness protection programmes are:

(a) A clear legal or policy basis for designing a methodology and carrying out operations;

(b) Adequate financing that is stable and continues for several years;

(c) Strict personnel qualifications and vetting procedures;

(d) Protection of the programme's integrity;

(e) Close coordination with judicial and other Government authorities engaged in law enforcement and intelligence, prison administration, public housing, health and social security services, among others;

(f) Accountability and transparency that conform with the programme's special Security needs;

(g) Obligation of government authorities to provide appropriate assistance, safeguarding the information disclosed to them;

(h) Ability to offer assistance to national and international law enforcement agencies. ${ }^{2}$

Witness protection programs management in Kosovo initially was under the International Police competencies within the United Nations Mission in Kosovo (UNMIK), then under the European Union mission of rule of law in Kosovo (EULEX) until completion of legislation and increasing mechanisms of local institutions. Currently, by the approval of law on witness protection in 2011 are set the legal provisions for implementation of witness protection programs by local institutions. According to Kosovo Law no. 04/I-015 on Witness Protection, Article 4 Grounds for application of protection measures, protection measures may be implemented before, during and after criminal proceeding for the endangered person with regard to the investigations for criminal offences as follows: criminal offence against Kosovo, its citizens and residents; criminal offence against international law; criminal offence against the economy; criminal offence against the official position; criminal offence which, as foreseen by the Law, is punishable by imprisonment of five (5) or more years. Protection measures may be applied towards the person related to above mentioned criminal offences if there is a serious threat to that person and his close persons and that person accepts to cooperate closely with the courts or investigatory authorities. While, the protection measures that can be initiated according to this law are stipulated in the Article 5 Types of Protection Measures. Protection measure is applied to ensure the protection for the protected person from serious threat against his life, physical or mental health or to close persons defined in this Law. Protection measures are as follows:

- $\quad$ physical protection of the protected person;

- $\quad$ temporary relocation of protected person to a secure place;

- $\quad$ special procedures for access to data and documents related to protected persons from offices for issuing the documents and other formal information databases;

- $\quad$ change of the protected person's place of residence, work or study;

- change of identity of the protected person;

- $\quad$ change of the protected person appearance, including plastic surgery;

- $\quad$ financial support for the protected person;

- $\quad$ social, legal and other necessary assistance for the protected person; and

- $\quad$ special regime for the protected person in custody, in correctional institutions.

\footnotetext{
1 http://www.unafei.or.jp/english/pdf/PDF_GG4_Seminar/Fourth_GGSeminar_P3-19.pdf

2 UNODC, Good Practices for the Protection of Witnesses in Criminal Proceedings Involving Organized Crime, United Nations Office on Drugs and Crime, UNITED NATIONS Wiena, 2008, pg.94
} 
Another important issue in witness protection is the process of decision making for initiation and administration of the program. Kosovo legislation establishes the decision making committee which is composed of three (3) members: Chief State Prosecutor of Republic of Kosovo, head of investigation unit of Kosovo Police and the director of the Witness Protection Directorate. Responsible body for the implementation of protection measures is Witness Protection Directorate (WPD) within the Kosovo Police (KP). The establishment and functionalization of this directorate was supported by international presence in Kosovo and by various projects in personnel training, drafting work procedures and implementing professional standards. "The EU-financed project "Witness Protection in the Fight against Serious Crime and Terrorism II" (WINPRO II) is progressing within slightly delayed timelines. EULEX, WINPRO and the KP are in a final stage of completing the revision of the organizational structure of the Kosovo Police Witness Protection Directorate (KPWPD), the job descriptions for KPWPD, the secondary legislation as well as the relevant Standard Operating Procedures. The Administrative Instructions were already approved by the MolA."1

\section{Conditions and challenges for implementing Witness Protection Program}

The abilities and conditions for successful implementation of witness protection programs should be viewed from the perspective of existence of functional and competent mechanisms for program management and the legal bases defining standards for the competent officer's accountability and prevention of misuse, arbitrariness and human rights violation. From the legal perspective, conditions for inclusion of witnesses in protection programs are clearly determined. Kosovo Law on witness protection, Article 22 Conditions for inclusion in the program stipulates that when deciding regarding the proposal for inclusion in the program, Committee shall take into consideration following criteria:

1. the importance of the information which is acceptable as testimony in the main trial that cannot be provided from any alternative source. Request for the inclusion in the program should contain information that the proposed person for inclusion in the program regarding criminal offence, perpetrators and other important data and information which are necessary and substantial for the prosecution of the criminal offence;

2. seriousness of the threat;

3. willingness of the proposed person for inclusion into the program to cooperate with courts or investigatory authorities while implementing the program.

4. suitability of the proposed person for inclusion in the program to act in accordance with the program and creating a belief that the witness relocation will not cause any danger to life or health of others.

After the decision for inclusion into the program of the endangered person, written consent and completed questionnaire of the person included into the program will be protected and archived by the witness protection Directorate. After concluding a special agreement between witness protection Directorate and any person at risk, such person shall be considered as protected person. ${ }^{2}$ Except the legal bases, progress in strengthening operational capacities was positively evaluated. "Progress in the area of witness protection is noticeable and the Kosovo Department of Witness Protection is on its way towards full operational capability. Necessary administrative instructions have been prepared and Memoranda of Understandings with relevant state authorities, as well as with some partner countries, have been signed. Further work is ongoing to create the necessary preconditions for the KP WPD to begin taking on cases. ${ }^{3}$

Despite the progress in establishing legislation and building mechanisms for implementing protective measures, Kosovo Institutions face some challenges in implementing witness protection programs. Initially, in the geographical aspect, implementation of programs within Kosovo is almost impossible and the only opportunity is taking witnesses under protection to another state, but in the aspect of international cooperation, Kosovo faces some challenges by not being member of important international organizations as a result of political obstacles. High level of corruption in the country creates insecurity and distrust in responsible institutions for implementing protection measures as well as reflects lack of political will in combating crime in general. Besides this, the concept of witness protection requires time for education and awareness rising of responsible actors. Another challenging issue in successful implementation of witness protection

\footnotetext{
1 EULEX Kosovo, Compact Progress Report, 2014,pg.11

2 Law no. 04/I-015 on Witness Protection, Kosovo, 2011.pg.10

3 EULEX Kosovo, Compact Progress Report , Prishtina, 2014, pg.5 
programs is the financial part as well, considering Kosovo's budgetary abilities and cost carrying witness protection program.

\section{Conclusion}

In order to effectively prevent and fight serious and organized crime and terrorism there is a need for state institutions for updating legal infrastructure and policies, building new mechanisms, strengthening existing mechanisms, assigning belateral and multi-lateral agreements, sharing knowledge and experiences and also coordinating activities in one side and in the other side preparing and building capacities to manage effectively witness protection programs.

The role and importance of witnesses in crime combating is an irreplaceable one. Kosovo made progress in establishing legal infrastructure and mechanisms in implementing witness protection measures and at the same time faces some challenges in the aspect of international cooperation, education and awareness raising of the responsible actors, social, cultural and geographical factors as well as in the logistics aspect for financing witness protection programs.

\section{Referneces}

[1] Criminal No. 04/L-123 Procedure Code of Kosovo, 2013.

[2] EULEX Kosovo, Compact Progress Report, Prishtina, 2014.

[3] European Commission, Kosovo Progress Report 2014

[4] http://www.eulex-kosovo.eu/en/news/000502.php (08/11/2015)

[5] http://www.unafei.or.jp/english/pdf/PDF_GG4_Seminar/Fourth_GGSeminar_P3-19.pdf (11/11/15)

[6] Law no. 04/l-015 on Witness Protection, Kosovo, 2011.

[7] OSCE, Witness Security and Protection in Kosovo; Assessment and Recommendations, OSCE Mission in Kosovo, 2007

[8] Smibert, Jon. Guide to the Criminal Procedure Code of Kosovo, Office of Overseas Prosecutorial Development and Training, US Embassy, Prishtina 2013

[9] UNODC, Good Practices for the Protection of Witnesses in Criminal Proceedings Involving Organized Crime, United Nations Office on Drugs and Crime, UNITED NATIONS Wiena, 2008 